\title{
Current Status of Reproductive Management in Bali Cows in South Sulawesi Province, Indonesia
}

\author{
Sudirman Baco, Muhammad Yusuf, Basit Wello, Muhammd Hatta \\ Department of Animal Production, Faculty of Animal Science, Hasanuddin University, Makassar, Indonesia \\ Email: sudirmanbaco@gmail.com
}

Received July 2013

\begin{abstract}
The objective of this study was to elucidate the current status of reproductive management of Bali beef cows in south Sulawesi Province, Indonesia. This study was conducted in Bantaeng Regency, South Sulawesi Province, Indonesia. Purposive sampling was used to choose the location where the study was taking place with consideration that this region has potential place for Bali cows. Data collection both primary and secondary data was done through observation and interview to obtain both quantitative and qualitative data. The results of this study showed that reproductive management applied to Bali cows in this region was very low. However, knowledge of the farmers regarding reproductive management such as estrus and its signs were much better, although the time of insemination to the estrous cows sometimes was too late. Mating system of Bali cows in this area were two different methods; natural mating and artificial insemination (AI). To adopt AI technology, the farmers should follow the standard operation of this technology. This study also showed that most of the farmers had good knowledge about estrus synchronization; however, they are still having difficulty to obtain or to access this technology, especially the price of the hormones used for estrus synchronization.
\end{abstract}

Keywords: Bali Cows; Reproductive Management; Estrus; Mating System

\section{Introduction}

Reproductive efficiency has long been recognized as the most important aspect of commercial beef production (Dyer, 2009). For a cow-calf operation, good reproductive rates are critical to operational success and profitability (Parish, 2010). Furthermore he stated that cows that do not produce calves on at least annual basis use resources that could be better used to support more productive cattle. Therefore, closely monitor cattle reproductive efficiency to identify and address reproductive problems quickly. This means that it is necessary to manage the reproductive cows to achieve high level of profitability. However, to manage the reproductive rate of beef cattle, it is important to assess or measure the reproductive efficiency of the cattle as well as reproductive management that applied in the herds.

In South Sulawesi Province, Indonesia, Bali cattle are the type of beef cattle that are commonly raised by the farmers. This type of beef cattle has many advantages in rising according to the farmers' perception in this region. For example, this cattle has better reproductive performance, high tolerance to the heat stress, and having dual purpose for draught and for beef. These reasons make the farmers to maintain this type of cattle with them. However, since this type of beef cattle used for draught in the field, in which affecting their reproductive performance to produce many offspring during their lifetime, for a few last years their reproductive performance was decreased. This is probably caused by low level of reproductive management applied by the farmers. However, to our knowledge, there was no study to describe the reproductive management of Bali beef cows in this region. Therefore, this study tried to elucidate the current status of reproductive management of Bali beef cows in south Sulawesi Province, Indonesia.

\section{Materials and Methods}

\section{Animals and Management}

A total of 130 cows from 25 farmers in Bantaeng Regency, South Sulawesi Province, Indonesia were involved the present study. The Bali cows were raised in a small holder system without any modern technology involved. The housing system for the animals was in the simple house during nighttime and free during daytime for grazing without any additional feeds such as concentrate, mineral, and feed additive. The cows are usually sent out in the morning time to the field for grazing and return back in the late afternoon. During grazing, some owners of Bali cows sometimes observe their animals for estrous signs. Animal showed signs of estrus were naturally mated with the bull if available at the time of estrus or inseminated by inseminator.

\section{Data Collection}

For reproductive management and the development of Bali cattle population, both primary and secondary data were used in the study. Primary data was collected with the help of a questionnaire to the 25 farmers that included raising management and reproductive management. While secondary data was collected from related institution such as local government and livestock service. Clinical examination was implemented by the authors with the help of local technician and/or management staffs of the herd. All cows were subjected to trans-rectal palpation for pregnancy status and/or the genitalia to assess uterine conditions and ovarian structures. Trans-rectal palpation of the 
uterine was performed to determine the consistency of uterine including contraction, elasticity, tonicity, symmetry of uterine horns, and the presence of any fluid in the uterus (Gautam et al., 2010). The presence of any palpable ovarian structures, ovarian cysts was defined as one or more follicle-like structures $>25$ $\mathrm{mm}$ in diameter without a concurrent corpus luteum (CL). Ovaries without palpable structures (i.e. ovarian follicles $>10 \mathrm{~mm}$ in diameter and/or a functional CL) were considered inactive (Yusuf et al., 2010).

\section{Results and Discussion}

\section{Reproductive Management of Bali Cows}

In the present study, the farmers were interviewed regarding the simple reproductive management applied for their Bali cows, such as cow and heifer management, knowledge about puberty, estrus and its signs, reproductive disorders, mating system, estrous synchronization, and calving management. For cow and heifer management, mostly farmers did not pay special attention to how efficient their cattle will produce as many as calves during her lifetime. One main problem facing the Bali cows after calving was the duration of anestrus (Yusuf et al., 2012a). Prolonged postpartum anestrus in suckled beef cows is one of the main restrictions to obtain a calf every year (Miller \& Ungerfeld, 2008). Short et al. (1990), Stated that prolonged suckling, nutritional deficiencies, climatic stress, parity, time of the year, and management practices were the main causes of prolonged calving intervals. However, in many cases, the farmers did not realize this condition. Therefore, effort to reduce this problem is necessary. The duration of anestrus in cattle was usually shortened when cows exposed to bulls (Rekwot et al., 2000; Landaeta-Hernández et al., 2004; Miller \& Ungerfeld, 2008). Likewise, regular examination of postpartum cows in order to achieve shortening the duration between calving and first estrus seems to be one of solving the problems (Yusuf et al., 2012a).

In heifers, there was no selection of replacement beef heifers on genetic improvement and phenotype. Parish (2010) stated that for cow and heifer management, it should be considered indicators of reproductive performance when selecting replacements. In addition, it is important to have heifers cycling before the first breeding season to ensure the highest possible fertility at first service. The other thing that the farmers in this region did not pay attention was the age of heifers at first breeding and probability of heifers' age at first calving.

In the present study, knowledge of the farmers regarding estrus and its signs was quite good. They knew both primary and secondary estrus signs. When the signs of estrous occurred in their cows, especially standing estrus, they had a good effort to mate the cows with the bull or they inform to the inseminator to inseminate their cows as soon as possible. However, in many cases, it was often the time of insemination was too late. This indicated when the authors asking the inseminator especially uterine tone condition at the time of insemination was not in contraction. This suggests that although the knowledge of the farmers was much better about estrus signs but the time of insemination should also be improved.

For reproductive disorders, all farmers described no idea regarding this problem for their cows. Anestrus postpartum was the main problem in this region. Long duration of postpartum anestrus was the major reproductive disorders facing their cows
(Yusuf et al., 2012b). In addition, there was no treatment conducted for this problem. The authors tried to introduce reproductive management for anestrus cows with the use of hormonal treatment to shorten the interval from calving to first service. This was not accepted well since the farmers have difficulty to buy such kind of hormones. For instant, introduction of GnRH or progestin (CIDR) by authors for free to the farmers seemed to be successful. However when authors stopped this program, there was no more treatment conducted by the farmers for this reproductive problem.

In the present study, we have tried to assess the reproductive physiology of all the cows as shown in Table 1 (Yusuf et al., 2012b).

Based on clinical examination of Bali cows as shown in Table 1, it indicated that in a population of these cattle, there were $37 \%$ cows become pregnant after repeating insemination or natural mating. The remaining 63\% cows were not pregnant with various reproductive statuses. For these high non-pregnant cows required special attention to increase the number of cows to become pregnant. This means that it is necessary to improve reproductive management in Bali cows to achieve the highest level of pregnancy rate as well as to shorten the calving interval among the cows. Therefore, an effort to increase the reproductive efficiency in Bali cattle in this region is necessary in order to increase both population and profitability to the farmers.

Table 1.

Results of clinical examination of Bali cows.

\begin{tabular}{lcc}
\hline Variable & No. of cows & Percentage (\%) \\
\hline No. of animal & 111 & 100 \\
Pregnant cow & 41 & 37 \\
Non-pregnant & 70 & 63 \\
Cyclic & 15 & 14 \\
$\quad$ Cyclic + nimpomania & 1 & 1 \\
Cyclic + metritis & 1 & 1 \\
Anestrus & 52 & 47 \\
Anestrus + metritis & 1 & 1 \\
\hline
\end{tabular}

\section{Future Prospect to Improve Reproductive Management in Bali Cows}

Since potential good reproductive performance of Bali cows in this region occurred in the past time, it is not difficult to improve this potential in the future. Improvement in reproductive management as well as nutrition especially micro-nutrient would be the way out to increase the population of Bali cattle through improvement of reproductive performance by conducting good reproductive management.

The present study concluded that the reproductive management in Bali cows was very low. Farmers' knowledge and limitation to the skills to manage the cows were the major factors for this problem. However, to improve the reproductive performance of Bali cows, it is necessary to improve the farmers' knowledge as well as skill in raising animals.

\section{REFERENCES}

Dyer, T. G. (2009). Reproductive management of commercial beef cows 
(pp. 1-7). Cooperative extension. The University of Georgia and Ft. Valley State College, the US Department of Agriculture and Counties of the State Cooperating.

Gautam, G., Nakao, T., Koike, K., Long, S. T., Yusuf, M., Ranasinghe, R. M. S. B. K., \& Hayashi, A. (2010). Spontaneous recovery or persistence of postpartum endometritis and risk factors for its persistence in Holstein cows. Theriogenology, 73, 168-179. http://dx.doi.org/10.1016/j.theriogenology.2009.08.010

Landaeta-Hernández, A. J., Giangreco, M., Meéndez, P., Bartolomé, J., Bennet, F., \& Rae, D. O. (2004). Effect of biostimulation on uterine involution, early ovarian activity and first postpartum estrous cycle in beef cows. Theriogenology, 61, 1521-1532.

http://dx.doi.org/10.1016/j.theriogenology.2003.09.002

Miller, V., \& Ungerfeld, R. (2008). Weekly bull exchange shortens postpartum anestrus in suckled beef cows. Theriogenology, 69, 913917. http://dx.doi.org/10.1016/j.theriogenology.2007.12.012

Parish, J. A. (2010). Reproductive management of beef cattle herds (pp. 1-5). Extension Service. Mississippi State University.

Rekwot, P. I., Ogwu, D., \& Oyedipe, E. O. (2000). Influence of bull biostimulation, season and parity on resumption of ovarian activity of zebu (Bos indicus) cattle following parturition. Animal Reproduction Science, 63, 1-11.

http://dx.doi.org/10.1016/S0378-4320(00)00163-9

Short, R. E., Bellows, R. A., Staigmiller, R. B., Berardinelli, J. G., \& Custer, E. E. (1990). Physiological mechanisms controlling anestrus and infertility in postpartum beef cattle. Journal of Animal Science 68, 799-816.

Yusuf, M., Nakao, T., Ranasinghe, R. M. S. B. K., Gautam, G., Long, S. T., Yoshida, C., Koike, K., \& Hayashi, A. (2010). Reproductive performance of repeat breeders in dairy herds. Theriogenology, 73, 1220-1229. http://dx.doi.org/10.1016/j.theriogenology.2010.01.016

Yusuf, M., Rahim, L., Asja, M. A., \& Wahyudi, A. (2012a). The incidence of repeat breeding in dairy cows under tropical condition. $\mathrm{Me}$ dia Peternakan, 35, 28-31.

http://dx.doi.org/10.5398/medpet.2012.35.1.28

Yusuf, M., Toleng, A. L., \& Hasbi, N. S. (2012b). Reproductive disorders in Bali cows raised under small-holders (a preliminary study). In Proceedings on Seminar National for Livestock Sustainability (in Indonesian language) (pp. 9-14). 